\title{
Urgensi Larangan Penggunaan Senjata Kimia di Suriah menurut The Chemical Weapon Convention 1993
}

\author{
Ar Raffi Ridho; Retno Kusniati \\ Fakultas Hukum Universitas Jambi \\ *Corresponding author : arraffiridho8@gmail.com \\ Submission : 16 November 2021 \\ Revision : :17 Desember 2021 \\ Publication : :18 Februari 2022
}

\begin{abstract}
.
This article discusses the application of The Chemical Weapons Convention 1993 "CWC" in the prohibition of the Use of Chemical Weapons and analyzes the protection of victims against the impact of the use of chemical weapons in Syria. The research method used is a normative juridical research type. The results showed that the application of The Chemical Weapons Convention 1993 "CWC" in the prohibition of the use of chemical weapons is a violation according to the provisions of international humanitarian law. Meanwhile, the settlement of cases of the use of chemical weapons by the OPCW and the United Nations is only limited to the destruction of chemical weapons by the Syrian side without any other sanctions. Based on Article 27 of Geneva Convention IV 1949, the protected person has the right, in all circumstances to obtain respect for himself, his dignity, the rights of his family, religious beliefs and worship, customs and customs.
\end{abstract}

Keywords: chemical weapons; humanitarian law; syrian war; 


\begin{abstract}
Abstrak
Artikel ini membahas mengenai penerapan The Chemical Weapons Convention 1993 “CWC” dalam larangan Penggunaan Senjata Kimia serta menganalisis perlindungan korban terhadap dampak penggunaan senjata kimia di Suriah. Metode penelitian yang digunakan adalah tipe penelitian yuridis normatif. Hasil penelitian menunjukkan bahwa penerapan The Chemical Weapons Convention 1993 "CWC" dalam larangan penggunaan senjata kimia adalah sebuah pelanggaran menurut ketentuan hukum humaniter internasional. Sementara itu, penyelesaian kasus penggunaan senjata kimia oleh OPCW dan PBB hanya sebatas pemusnahan senjata kimia oleh pihak Suriah tanpa ada pemberian sanksi lainnya. Berdasarkan Pasal 27 Konvensi Jenewa IV 1949, orang yang dilindungi berhak, dalam segala keadaan untuk memperoleh penghormatan atas dirinya, martabatnya, hak-hak keluarganya, keyakinan dan ibadah keagamaannya, kebiasaan serta adat-istiadatnya.
\end{abstract}

Kata Kunci: hukum humaniter; senjata kimia; perang suriah;

\title{
A. Pendahuluan
}

Perang merupakan hal yang sudah tidak asing bagi manusia. Karena perang memiliki catatan sejarah yang sama jangka waktunya dengan sejarah umat manusia. dapat terlihat pada kalimat "Armed conflict is as old as humankind itself." Beberapa studi menyebutkan bahwa perang adalah sebuah fenomena yang tidak dapat terelakkan. Perihal tersebut

${ }^{1}$ War and International Humanitarian Law. dimuat dalam http://www.icrc.org/eng/war-and-law/overview-war-and-law.html. diakses pada 30 September 2020, Pukul 11:06 WIB

Uti Possidetis: Journal of International Law, Vol. 3, No. 1 (2022) 
didasari bahwa didalam diri manusia terdapat sebuah naluri secara alami untuk melukai atau menyerang orang lain. ${ }^{2}$

Pasal 3 Konvensi Jenewa 1949 dapat ditemukan bahwa perang adalah suatu perbuatan yang mengandung unsur kekerasaan terhadap kehidupan orang, khususnya pembunuhan dari segala jenis, pemotongan bagian tubuh, perlakuan kejam, dan penyiksaan. Dalam arti yang lebih luas, perang berkaitan dengan konsep-konsep berupa krisis, aksi gerilya disertai dengan kekerasan, pendudukan, ancaman, penaklukan, hingga teror. Perang telah lama diterima sebagai salah satu cara yang sah untuk mengatasi berbagai persoalan ketika berbagai macam cara telah menemui jalan buntu untuk menyelesaikan berbagai masalah.

Akan tetapi, meskipun perang telah diterima untuk menyelesaikan suatu masalah, namun pada hakikatnya setiap negara pasti akan melakukan percobaan untuk melindungi individu-individu dari dampak terburuk dari perang sepanjang sejarah. Saat tahun 1815 di Kongres Wina ditandatangani, isinya terdapat peraturan utama yang berkembang pada saat itu, antaranya adalah: ${ }^{3}$

${ }^{2}$ Ambarwati, dkk. Hukum Humaniter Internasional dalam Studi Hubungan Internasional. Cetakan Pertama, Rajawali Pers, Jakarta, 2009. hal. 4.

${ }^{3}$ T.A. Couloumbus and James H. Wolfe. Introduction to International Relations: Power and Justice. New Jersey: Prentice hall Inc., 1990. hal. 262.

Uti Possidetis: Journal of International Law, Vol. 3, No. 1 (2022) 
a. Perang diumumkan terlebih dahulu sebelum perang dimulai

b. Combatant wajib menggunakan seragam yang berbeda agar dapat dibedakan dengan Non-Combatant

c. Pengrusakan, pembunuhan, dan penghancuran harus dapat dibedakan dengan kebutuhan militer (military necessity)

d. Yang boleh dibom atau dihancurkan adalah sasaran militer

e. Tawanan perang tidak boleh dibunuh atau dianiaya, dan wajib untuk diberi makan dan pakaian serta harus dijaga kesehatan nya selama ditahan.

f. Perawat rumah sakit (Red cross) dan kendaraan yang bertanda Bulan Sabit Merah wajib dibebaskan dari serangan militer.

g. Museum dan gedung yang memiliki unsur sejarah, serta tempat-tempat suci termasuk kota-kota yang dijaga dan atau tidak dipertahankan tidak boleh di bom.

h. Penduduk di wilayah yang ditempati wajib dijaga dan dipimpin dengan perlakuan yang baik, wanita dan anakanak tidak boleh diperkosa.

i. Hak yang bersifat milik pribadi boleh diambil dengan syarat ganti rugi yang pantas.

Walaupun telah terdapat peraturan-peraturan yang dilarang untuk dilakukan dalam peperangan, masih ada hal-hal yang dilarang namun tetap dilanggar oleh negara-negara yang ada, Suriah misalnya. Pelanggaran tersebut menyebabkan 
pertentangan dengan apa yang terdapat di dalam prinsip Hukum Humaniter Internasional, mengenai Prohibition of Causing Unnncessary Suffering yaitu: Dilarang menggunakan metode atau cara peperangan tertentu atau yang dapat diharapkan untuk merusak lingkungan yang meluas, berjangka panjang, dan parah. ${ }^{4}$

Penerapan prinsip itu bertolak belakang dengan apa yang terjadi di Suriah. Sejak Maret 2011, konflik di Suriah belum menujukkan tanda-tanda akan berakhir. Menurut data Persatuan Bangsa-Bangsa (PBB) pada Juli 2013, pemberontakkan tersebut telah menewaskan 100.000 orang lebih, 4 juta warga sipil harus meninggalkan rumah mereka, 2 juta anak terpaksa putus sekolah dan 1 juta orang telah meninggalkan negara itu. ${ }^{5}$

Ada pula yang berpendapat bahwa pemicu dari perang di Suriah adalah akibat persekongkolan multinasional. Secara umum, sebuah konflik memiliki empat faktor yang dianggap sebagai alasan terjadinya konflik tersebut yakni triggers (pemicu), privotal (akar), mobilizing (para pemimpin) dan agravating (faktor yang memperburuk atau memancing situasi konflik). ${ }^{6}$ Konflik di Suriah merupakan fenomena Arab Spring ${ }^{7}$

4 Protokol Tambahan I / 1977, Pasal 35 ayat (3)

${ }^{5}$ Arnav Mariwala, The Syrian Civil War Regime of Bashar Al Assad. Standford Model United Nation Conference (2014). hal. 15.

6 Sholihan, "Memahami Konflik," dalam Mukhsin Jamil (Ed), Mengelola Konflik Membangun Damai, Wali Songo Media Center, Semarang 2007. hal. 5.

Uti Possidetis: Journal of International Law, Vol. 3, No. 1 (2022) 
yang telah meluas di kawasan semenanjung Arab. Konflik ini menjadi kompleks karena terlibatnya berbagai aktor hukum internasional seperti Negara-Negara besar, kelompok pendukung pemerintah, serta kelompok oposisi dalam hal ini pemberontak.

Konflik di negara Suriah adalah konflik yang terjadi antara pemerintah dan rakyat sipil mereka sendiri. Pada tahun 2011, pemicu dari konflik di Suriah adalah pecahnya perang saudara di Suriah. Selain itu penyebab lainnya adalah perbedaan sekte agama yang terjadi di Suriah dimana negara tersebut didominiasi oleh kaum Sunni namun Assad dikenal sebagai kaum Alawite. hal tersebut merupakan bentuk dari ketidakpuasan rakyat Suriah terhadap pemerintahan Presiden Bashar Al Assad. Ketidakpuasan tersebut ditunjukkan dengan berbagai aksi demostrasi dan protes di Negara tersebut yang mendesak agar Presiden Bashar Al Assad mundur dari jabatannya.

Perang di Suriah mendapatkan perhatian internasional. Berbagai bantuan asing telah dikirim. Bukan Cuma untuk pemerintah Suriah, namun juga kepada pemberontak. hal ini menegaskan bahwa terdapat kepentingan pihak asing terhadap negara tersebut. Kepentingan asing yang sangat

${ }^{7}$ Arab Spring atau kebangkitan negara arab adalah istilah dari barat untuk menyebut kondisi dimana negara-negara Arab telah memulai transisi dimana yang pada awalnya adalah negara dengan sistem monarki menuju sistem demokrasi. hipm.ac.id/membaca the arab spring.

Uti Possidetis: Journal of International Law, Vol. 3, No. 1 (2022) 
menonjol adalah ekonomi. Misalnya Rusia yang telah mengirim delegasinya untuk memberikannya dukungan terhadap pemerintahan Assad. Begitu pula dengan Iran, yang tidak hanya membantu berupa dukungan diplomatik dan penyediaan senjata, negara tersebut bahkan memberikan dukungan berupa anggota militer dan bantuan finansial sebesar lebih dari \$ 9 Miliar. ${ }^{8}$ Namun, negara Amerika Serikat dan Sekutu yang mendukung pihak oposisi yang dalam hal ini adalah pemberontak telah mengirimkan bantuan berupa logistik dan senjata. Bantuan ini yang disalurkan ini digunakan untuk mendesak agar presiden Bashar Al Assad lengser dari kursi kepresidenan.

Di antara berbagai serangkaian penggunaa senjata kimia di Suriah, yang paling memiliki dampak yang besar adalah serangan dengan menggunakan Gas Sarin ${ }^{9}$ pada tahun 2013 di Ghouta Timur dan pada tahun 2017 di desa Khan Sheikhoun di Idlib. ${ }^{10}$ Organisasi pemantau HAM Suriah, atau yang dikenal dengan Syrian Observatory for Human Rights (Observatorium

8 Mariwala, "The Syrian Civil War Regime of Bashar Al Assad."

${ }^{9}$ Gas Sarin Merupakan senyawa organofosfat sintetik yang sangat beracun. Sebuah cairan takberwarna dan takberbau, mimiliki potensi ekstrem https://id.wikipedia.org/wiki/Sarin diakses pada tanggal 23 februari 2021 pukul 13:05 WIB

${ }^{10}$ Niken Purnamasari. Mengenal Gas Sarin yang Membunuh Perlahan Anak-anak Suriah. https://news.detik.com/berita/d3467871/mengenal-ganasnya-gas-sarin-yang-membunuh-perlahananak-anak-suriah. Diakses pada tanggal 29 Desember 2020 Pukul 15:44 WIB

Uti Possidetis: Journal of International Law, Vol. 3, No. 1 (2022) 
Suriah untuk Hak Asasi Manusia), menjelaskan bahwa serangan yang terjadi diyakini dilakukan oleh jet tentara Suriah. Dampak dari serangan ini membuat banyak orang mengalami masalah kesehatan seperti mendadak tersedak, bahkan beberapa korban juga mengeluarkan busa dari mulut mereka. Rata-rata yang mengalami gejala tersebut adalah anak-anak di bawah usia delapan tahun. Terdapat alasanalasan yang jelas dalam hukum humaniter internasional terkait larangan penggunaan senjata-senjata. Alasan tersebut dimuat dalam Deklarasi St. Petersburg tahun 1868, dan diperkuat lagi dalam The Hague Regulations tahun 1907 serta Protokol Tambahan I tahun 1977.

Pelarangan penggunaan senjata-senjata tertentu oleh Deklarasi St. Petersburg tahun 1868, di antaranya: 11

"Considering: That the progress of civilization should have the effect of alleviating as much as possible the calamities of war; That the only legitimate object which States should endeavour to accomplish during war is to weaken the military forces of the enemy; That for this purpose it is sufficient to disable the greatest possible number of men; That this object would be exceeded by the employment of arms which uselessly aggravate the sufferings of disabled men, or render their death inevitable; That the employment of such arms would, therefore, be contrary to the laws of humanity"

11 Practice Relating to Rule 70. Weapons of a Nature to Cause Superfluous Injury or Unnecessary Suffering, www.icrc.org/customary -ihl/eng/docs/v2 rulrule70, diakses pada 18 September 2021 pukul 17.15 WIB

Uti Possidetis: Journal of International Law, Vol. 3, No. 1 (2022) 
Deklarasi St. Petersburg tahun 1868 menegaskan dengan pertimbangan peradaban yang mau memberikan dampak pengurangan sebanyak mungkin malapetaka dari perang; bahwa satu-satunya sasaran yang sah yang mana harus diselesaikan suatu negara ketika perang ialah melumpuhkan kekuatan dari pasukan bersenjata; bahwa untuk mencapai tujuan ini, cukup dengan mengalahkan pasukan lawan sebanyak mungkin; bahwa pemakaian senjata yang berlebihan dapat memperburuk penderitaan dari orang yang menderita lumpuh atau bahkan membuat kematian menjadi tak terhindarkan dan membuat tujuan ini menjadi berlebihan; maka dari itu, pemakaian senjata yang dilarang merupakan pelanggaran hukum internasional. Pada tahun yang sama hal serupa juga tejadi di Ltamenah. Dikutip dari situsi OPCW penggunaan senjata kimia jenis Sarin tercatat pada tanggal 24 Maret 2017.

"The Organisation for the Prohibition of Chemical Weapons (OPCW) released today the findings of the OPCW Investigation and Identification Team (IIT). At approximately 6:00 on 24 March 2017, an Su-22 military airplane belonging to the 50th Brigade of the 22nd Air Division of the Syrian Arab Air Force, departing from Shayrat airbase, dropped an M4000 aerial bomb containing sarin in southern Ltamenah, affecting at least 16 persons." 12

12 Opcw. OPCW Releases First Report by Investigation and IdentificationTeam.https://www.opcw.org/mediacentre/news/202 
The Chemical Weapon Convention 1993 menyatakan dengan tegas mengenai pelarangan penggunaan senjata kimia didalam peperangan. Meskipun telah terdapat deklarasi St. Petersburg tahun 1868, dan Konvensi Den Haag tahun 1899. Senjata kimia masih dipakai dalam perang di negara Suriah. Protokol Jenewa 1925 telah melarang penggunaan senjata biologi dan senjata kimia namun tidak melarang pengembangan, produksi, penimbunan, atau penyebarannya, serta tidak mengatur mengenai mekanisme dan prosedur penanganan dalam hal terjadi pelanggaran. Kemudian dibentuklah The Chemical Weapon Convention 1993 yang menyatakan dengan tegas terkait penggunaan senjata kimia pada umumnya, yang berarti pada masa damai atau konflik bersenjata. Terdapat beberapa bentuk sanksi yang dapat dikenakan kepada pihak yang bersengketa dalam konflik di Suriah.

Dalam hal penegakkan terhadap penggunaan senjata kimia di dalam peperangan membutuhkan teori-teori hukum yang mendukung. Pada dasarnya terdapat teori-teori hukum yang berkembang., salah satunya adalah Teori Hak Asasi Manusia (HAM) Universal. Hak Asasi Manusia adalah hak yang telah melekat pada hakikat dan keberadaan manusia, kodrati dan alami sebagai makhluk Tuhan Yang Maha Kuasa,

0/04/opcw-releases-first-report-investigation-and-identificationteam. Diakses pada tanggal 29 Desember 2020 Pukul 15:44 WIB

Uti Possidetis: Journal of International Law, Vol. 3, No. 1 (2022) 
oleh karena itu HAM adalah suatu bentuk keadilan yang berhak untuk diperjuangkan oleh setiap individu. Jika arti dari kata keadilan dimaknai sebagai kebahagiaan sosial, maka kebahagiaan sosial itu akan tercapai jika kebutuhan dari individu sosial tersebut terpenuhi.

Dalam hal upaya untuk penegakkan hukum pada dasarnya memiliki tujuan untuk memberikan rasa aman kepada seluruh subyek hukum tersebut, di mana Hak Asasi Manusia (HAM) merupakan hak yang sudah dibawa sejak lahir, oleh karena itu penegakan HAM adalah hak yang wajib diperoleh oleh setiap individu.

\section{B. Pembahasan}

Dikemukakan oleh Mochtar Kusumaatmadja. Pembagian hukum humaniter menurut nya diantaranya, sebagai berikut:13

1. Jus ad bellum. Atau yang dikenal dengan hukum tentang perang,; yang mengatur mengenai bagaimana sebuah negara dapat dibenarkan menggunakan kekerasan bersenjata;

2. Jus in bello. Atau yang lebih dikenal dengan hukum yang berlaku didalam perang, kemudian hal tersebut dibagi lagi menjadi 2 (dua) aspek yaitu:

a. Hukum yang mengatur bagaimana cara dimulainya perang (conduct of war). Bagian ini biasanya disebut The Hague Laws.

b. Hukum yang mengatur mengenai bentuk tanggung jawab dan perlindungan terhadap para korban didalam peperangan. disebut The Geneva Laws.

13 Ibid.. hlm. 3

Uti Possidetis: Journal of International Law, Vol. 3, No. 1 (2022) 
Konflik perang sipil yang berkepanjangan selama lebih dari 10 (sepuluh) tahun sejak tahun $2011^{14}$ di Suriah telah menyebabkan lebih dari 5 juta jiwa penduduknya tewas dan lebih dari 10 juta menjadi pengungsi pada beberapa negara yang berbatasan dengan Suriah. ${ }^{15}$ Perang sipil Suriah ini ditenggarai telah menggunakan senjata kimia berupa gas syaraf sarin yang mematikan ${ }^{16}$. Penggunaan senjata kimia tersebut telah menyalahi ketentuan The Chemical Weapon Convention 1993 Terhadap Larangan Penggunaan Senjata Kimia Dalam Perang.

14 Perang Suriah dimulai pada Maret 2011 yang ditandai dengan terjadinya peristiwa pada 11 Maret 2011 ketika kelompok remaja menggambar slogan anti pemerintahan di kota Daraa. Slogan tersebut berisi ajakan untuk menggulingkan rezim Bashar al-Assad. Pemerintah Suriah menanggapi peristiwa tersebut dengan kekerasan. Kepolisian Suriah memenjarakan dan menyiksa seluruh pemuda yang dianggap terlibat dalam penyebaran slogan anti pemerintah. Tindakan represif kepolisian mengakibatkan aksi protes tambah meluas hingga ke kota-kota lain di Suriah. Gama Prabowo. Sejarah Terjadinya Konflik di Suriah.Dimuat dalamhttps://www.kompas.com/skola/read/2020/12/02/1432307 69/sejarah-terjadinya-konflik-di-suriah?page=all. Diakses pada tanggal akses 17 September 2021.

15 Republika Post. Konflik Suriah Lebih Lama dari Dua Perang Dunia. https://www.republika.id/posts/15027/konflik-suriahlebih-lama-dari-dua-perang-dunia.Diakses pada tanggal 17 September 2021.

16 Steffi, Tinjauan Hukum Internasional Terhadap Kasus Penggunaan Senjata Kimia Oleh Suriah, Jurnal Ilmiah Program Sarjana Ilmu Hukum Fakultas Hukum Universitas Sumatera Utara, Medan, 2014, hal. 13.

Uti Possidetis: Journal of International Law, Vol. 3, No. 1 (2022) 
Tindakan negara Suriah, dalam hal ini Presiden Bashar Alassad, dan pihak oposisi yang menggunakan senjata kimia dalam perang saudara sangat mengkhawatirkan dan mengkhawatirkan negara lain. Sebagai anggota Perserikatan Bangsa-Bangsa, Suriah berkewajiban untuk ikut serta dalam pemeliharaan perdamaian dunia dan keamanan internasional, sebagaimana diatur dalam Pasal 1, khususnya ayat 1 Piagam Perserikatan Bangsa-Bangsa. Perdamaian dan keamanan internasional". Penggunaan senjata kimia pada kenyataannya mengancam perdamaian dan keamanan dunia, dan konflik bersenjata di Suriah akibat penggunaan senjata kimia melanggar ketentuan Piagam PBB. Ancaman terhadap perdamaian dan keamanan dunia telah memaksa PBB dengan suara bulat menyetujui kerangka kerja untuk penghapusan senjata kimia Suriah.. ${ }^{17}$

Sebagai anggota Protokol Jenewa 1925, yang melarang penggunaan gas pencekikan, gas beracun, atau gas lainnya, Suriah harus mematuhi ketentuan Protokol Jenewa 1925. Serta pada Den Haag Convention 1907 atau dikenal sebagai Hukum Den Haag dimana hasil Konferensi Perdamaian Pertama tahun 1899, dan pada tahun 1907 konvensi ini disempurnakan dan diratifikasi oleh para pihak. Didalam Hukum Den Haag mengatur tentang alat dan cara berperang

17 Lihat Steffi. Tinjauan Hukum Internasional Terhadap Kasus Penggunaan Senjata Kimia Oleh Suriah. Jurnal Ilmiah. 2014, hal. 14.

Uti Possidetis: Journal of International Law, Vol. 3, No. 1 (2022) 
(means and methode of warfare). Konferensi Den Haag tahun 1907 menghasilkan 13 (tiga belas) konvensi dan 1 (satu) deklarasi, diantaranya sebagai berikut. ${ }^{18}$

1. Convention I for the Pacific Settlement of Disputes;

2. Convention II Respecting the Limitations of the Employment of Force for the Recovery of Contract Debts;

3. Convention III Relative to the Opening of Hostilities;

4. Convention IV Respecting the Laws and Customs of War on Land;

5. Convention $V$ Respecting the Rights and Duties of Neutral Powers and Persons in case of War on Land;

6. Convention VI Relating to the Status of Enemy Merchant Ships at the Outbreak of Hostilities;

7. Convention VII Relating to the Convention of Merchant Ships into War Ships;

8. Convention VIII Relating to the Laying of Automatic Submarine Contact Mines;

9. Convention IX Concerning Bombardment by Naval Forces in Time of War;

10. Convention $X$ for the Adoption to Maritime Warfare of the Principles of the Geneva Convention;

11. Convention XI Relative to Certain Restrictions with Regard to the Exercise of the Right of Capture in Naval War;

12. Convention XII Relative to the Creation of an International Prize Court;

13. Convention XIII Concertning the Rights and Duties of Neutral Powers in Naval War.

14. Declaration XIV Prohibiting the Discharge of Projectiles and Explosives from Balloons

18 Haryomataram, Pengantar Hukum Humaniter, Op. Cit., hlm.47.

Uti Possidetis: Journal of International Law, Vol. 3, No. 1 (2022) 
Konvensi pertama diatas mengatur tentang suatu persengketaan internasional dan tata cara penyelesaian damai. Konvensi ini telah diperluas dan diterima oleh Konvensi Den Haag 1907. Pelanggaran Suriah atas penggunaan senjata kimia berupa gas syaraf Sarin dalam perang sipilnya telah terjadi sebanyak 23 kasus. ${ }^{19}$ Menurut laporan "Organisation for the Prohobition of Chemical Weapons" selanjutnya di sebut OPCW, menyebutkan bahwa terdapat senjata kimia di suriah berupa gas Klorin.

OPCW selaku badan pelaksana "Convention on The Prohobition of The Development, Production, Stockpiling and Use of Chemical Weapons and on Their Destruction" saat ini disebut OPCW memiliki 192 negara anggota berkomitmen untuk mencapai dunia tanpa ada senjata kimia. Pada 16 Maret 2015 penggunaan senjata kimia ini terbukti telah digunakan oleh suriah di Sarmin, Provinsi Idlib, yang dilakukan oleh militer Suriah dengan mengebom barrel dan melepaskan zat beracun berupa Klorin, hal ini dapat dibuktikan dengan melihat laporan dari Joint Investigative Mechanism nomor S/2016/738 (Council, 2016: 10). Laporan tersebut merupakan

19 Didik Sugianto dan Arinto Nugroho, Pertanggungjawaban Penggunaan Senjata Kimia Oleh Suriah Pada Tahun 2014-2015 Ditinjau Dari Hukum Humaniter Internasional, Jurnal Ilmiah Fakultas Ilmu Sosial dan Hukum Universitas Negeri Surabaya, 2015. hal. 5 
mandat dari resolusi Dewan Keamanan nomor 2235 tahun 2015.20

Pada pasal 1 Konvensi Senjata Kimia menegaskan bahwa:

"Setiap Negara Pihak Konvensi ini wajib tidak pernah dalam keadaan apapun :

a. Untuk mengembangkan, memproduksi, jika tidak memperoleh, persediaan atau mempertahankan senjata kimia, atau pengalihan, langsung atau tidak langsung, senjata kimia kepada siapa pun;

b. Untuk menggunakan senjata kimia;

c. Untuk terlibat dalam persiapan militer untuk menggunakan senjata kimia;

d. Untuk membantu, mendorong, atau menyebabkan, dengan cara apapun, siapapun untuk terlibat dalam aktivitas yang dilarang untuk suatu Negara Pihak berdasarkan Konvensi ini."

Konvensi ini tidak menyebutkan larangan pemakaian bahan senyawa kimia untuk kegiatan industri pertanian, kesehatan, ataupun kegiatan dengan tujuan damai lainnya, namun dengan jelas melarang penggunaan senjata kimia. Penggunaan gas sarin juga telah melanggar Chemical Weapon Convention (1993), di mana Suriah juga merupakan negara peserta. hal ini menurut penulis dapat dilihat dari Pasal 1 Chemical Weapon Convention 1993, dimana dalam Pasal

${ }^{20}$ Lihat Didik Sugianto dan Arinto Nugroho, Pertanggungjawaban Penggunaan Senjata Kimia Oleh Suriah Pada Tahun 20142015 Ditinjau Dari Hukum Humaniter Internasional, Jurnal Ilmiah Fakultas Ilmu Sosial dan Hukum, Universitas Negeri Surabaya, 2015. hal. 2-3.

Uti Possidetis: Journal of International Law, Vol. 3, No. 1 (2022) 
tersebut dinyatakan bahwa setiap negara peserta konvensi ini, baik dalam keadaan apapun dilarang untuk mengembangkan, memproduksi, menyimpan serta memindahtangankan secara langsung maupun tidak langsung senjata kimia kepada siapa saja.

Meskipun Organisasi Pelarangan Senjata Kimia atau Organization for the Prohibition of Chemical Weapons (OPCW) pada dasarnya tidak mempunyai hak untuk melakukan pemeriksaan terhadap negara tersebut apakah menggunakan senjata dari bahan kimia maupun kegiatan yang berhubungan dengan senjata kimia. Namun menurut perjanjian kerjasama antara OPCW dan PBB, dalam penyelesaian kasus penggunaan senjata kimia oleh negara Suriah dalam konflik Bersenjata non internasional, PBB mempunyai otoritas untuk melakukan inspeksi. hal ini dapat dibuktikan dengan dokumen Implementasi serta pembuktian yg diatur dalam kesepakatan Senjata kimia bahwa OPCW wajib bekerja sama dengan PBB terkait dengan adanya dugaan penggunaan senjata kimia sang negara yg bukan pihak kesepakatan ataupun bukan wilayah territorial Negara Pihak.

Pada tanggal 16 Oktober 2013, OPCW dan PBB membentuk kerangka misi bernama "OPCW-UN Joint Mission". Badan kerja sama ini memiliki tugas untuk mengawasi program pemusnahan senjata kimia yang ada di Suriah. Program pemusnahan senjata kimia ini diatur pada pengaturan yang diadopsi OPCW dan didukung oleh PBB 
dengan membentuk Resolusi DK PBB “2118” tentang ketentuan tenggat waktu pemusnahan senjata kimia milik Suriah. Ketentuan waktu tersebut tentu saja berbeda dengan konvensi senjata kimia. hal ini dikarenakan Suriah bukan negara anggota dari konvesi tersebut.

Batas waktu yang djelaskan dalam kerangka kerja sama OPCW-UN Joint Mission menyebutkan bahwa pemusnahan senjata kimia milik Suriah harus selesai selambat-lambatnya sebelum tanggal 30 Juni 2014. hal ini dilakukan supaya pelaksanaan pemusnahan senjata dilaksanakan tepat pada waktu. Framework yang telah buat oleh AS bersama Federasi Rusia, mengatakan bahwa selambat-lambatnya pada tanggal 31 Desember 2013 bahan kimia yang paling berbahaya harus segera dikirim keluar, serta selambat-lambatnya tanggal 6 Februari 2014 bahan kimia berbahaya lainnya dikirim.

Namun, ketika pengiriman mengalami keterlambatan sampai pada tanggal 31 Desember 2013 dan 6 Februari 2014 membuat banyak pihak mempertanyakan niat baik Suriah dalam melaksanakan pemusnahan senjata kimia mereka. Atas kritik tersebut, rezim Bahsar $\mathrm{Al}$-assad merespon cepat pengiriman senjata kimia untuk dihancurkan agar target batas waktu pemusnahan senjata kimia Suriah tersebut tercapai dengan baik. ${ }^{21}$

Sesuai Statuta Roma, penggunaan senjata kimia oleh Suriah bisa digolongkan sebagai kejahatan perang dan ${ }^{21}$ Ibid. 
kejahatan terhadap kemanusiaan karena sudah memenuhi unsur di Pasal 8 Statuta Roma. Unsur-unsur tersebut adalah penggunaan racun, senjata beracun, maupun gas-gas yang dapat mengakibatkan sesak nafas. Pada kasus Suriah, negara tersebut menggunakan gas klorin yang dapat membuat dan mengakibatkan kematian jika di hirup dalam hitungan 1-10 menit. Namun, jika di pahami lebih lanjut penggunaan senjata kimia oleh Suriah juga telah memenuhi unsur pada Pasal 7 Statuta Roma, berupa dengan sengaja melaksanakan serangan pada objek non kombatan dan perbuatan tak manusiawi lainnya dengan tujuan memberikan luka berat ataupun luka yang serius pada fisik maupun. Akibat dari penggunaan senjata kimia ini telah melukai warga sipil yang dalam hukum humaniter mereka digolongkan sebagai non-kombatan dan bukan sasaran militer.

Pemakaian senjata kimia oleh Suriah dapat dikatakan pelanggaran terhadap ketentuan Protokol Jenewa 1925, dimana Suriah merupakan negara anggota dalam perjanjian internasional ini. Namun, pelanggaran ini bukan hanya terhadap protokol Jenewa 1925, tapi juga ketentuan Hukum Internasional dan Hukum Humaniter lainnya seperti Konvensi Den Haag 1907. Atas pelanggaran Suriah pada ketentuanketentuan yang sudah diatur oleh Hukum Humaniter Internasional, kelihatannya belum ada pemberian sanksi pidana kepada para pelaku pelanggaran Hukum internasional. Penyelesaian yang dilakukan pada kasus ini hanya sebatas 
pemusnahan senjata yang dimiliki Suriah oleh OPCW dan PBB. Jika dilihat lagi, Suriah adalah negara penandatanganan Statuta Roma 1998, jika dianalsis lebih dalam, perbuatan suriah menggunakan senjata kimia dapat dituntut pada pengadilan pidana internasional sehingga akan mendapatkan hukuman yang sesuai dengan kejahatannya.

Berdasarkan amanat dalam Statuta Roma tahun 1998, penyelesaian Kejahatan Perang di negara suriah dapat diselesaikan melalui Mahkamah Pidana Internasional. hal ini dikarenakan Mahkamah Pidana Internasional memiliki yurisdiksi untuk menyelesaikan penggunaan senjata kimia yang dikategorikan sebagai Kejahatan Perang dan Kejahatan Terhadap kemanusiaan. kasus-perkara yg terkait dengan penggunaan Senjata kimia pula bisa diselesaikan melalui penyelidikan OPCW yg sudah diamanatkan oleh Perjanjian Senjata Kimia tahun 1993, dan untuk Negara bukan Pihak kesepakatan OPCW dapat berkerja sama melalui PBB guna menangani kasus penggunaan senjata kimia.

Tindakan pemerintah Suriah dengan menggunakan gas sarin menandakan bahwa Suriah telah mengembangkan, memproduksi dan menyimpan gas sarin meskipun telah menjadi peserta dalam Konvensi ini. Kemudian dalam Ayat (2) dan (4) Pasal ini dinyatakan bahwa negara peserta wajib untuk menghancurkan segala senjata kimia dan fasilitas pengembangan atau penyimpanan senjata kimia yang berada dalam jurisdiksi atau wilayah negara masing-masing negara 
peserta konvensi. Fakta bahwa pada tahun 2017 tedapat serangan dengan gas sarin menunjukan bahwa pemerintah Suriah benar-benar mengabaikan Konvensi ini. Pelanggaran penggunaan senjata kimia oleh negara Suriah secara jelas dan tegas telah menyalahi ketentuan Chemical Weapon Convention (1993), menuntut adanya upaya penyelesaian berupa dilakukannya sejumlah tindakan sesuai hukum internasional yang berlaku.

Penegakkan hukum humaniter perlu dilakukan demi keadilan dan rasa kepuasan masyarakat internasional. Terkait dengan siapa subjek yang berkaitan penggunaan senjata kimia di Suriah, tentu saja subjek yang memiliki legal personality dan legal capacity hanyalah negara. Di sisi lain juga ada individu yaitu militer negara Suriah yang menjatuhkan bom barrel yang berisi Klorin sebagai subjek lainnya ya. BAB VI Pacific Settlement of Disputes, Pasal 33 ayat (1) yakni:

"The parties to any dispute, the continuance of which is likely to endanger the maintenance of international peace and security, shall, first of all, seek a solution by negotiation, enquiry, mediation, conciliation, arbitration, judicial settlement, resort to regional agencies or arrangements, or other peaceful means of their own choice".

Berdasarkan Pasal tersebut, hal pertama yang dilakukan dalam penyelesaian konflik yang terus menerus berlangsung serta akan membahayakn perdamaian dan keamanan internasional adalah mencari penyelesaian dengan 
cara perundingan, penyeledikian, mediasi, konsiliasi, arbitrase, ataupun penyelesaian menurut pengaturan regional maupun cara damai lainnya.

Dalam kasus penggunaan senjata kimia, penyelesaian secara diplomatik dinilai kurang efektif karena hanya didasarkan pada pertimbangan politik dan non yuridis. Penyelesaian secara politik dapat menjadi opsi pertama, namun penerapannya akan mengalami kendala, maka dari itu penyelesaian secara politik hanya cocok dalam menyelesaian permasalahan sengeketa antar negara. Penyelesaian menggunakan mediasi yang sebelumya dilakukan oleh Perserikatan Bangsa-Bangsa dengan menunjuk utusan Kofi Annan dan Lakhdar Brahimi supaya dapat membawa pesan damai dalam perang saudara di Suriah. Dan ditindaklanjuti dengan dikeluarkannya Resolusi DK PBB nomor 2118 tahun 2013 mengenai kecaman terhadap penggunaan senjata kimia dalam konflik di Suriah.

Mediasi yang telah dilakukan Kofi Annan tidak berjalan lancar, karena hanya terfokus pengembangan jalan keluar dari konfilk. Tentu saja hal ini sangat membingungkan dalam mencapai konsensus, disisi lain Lakdhar Brahmi mencoba menerapkan dengan menjelaskan berbagai rincian yang dipersoalkan untuk mencapai kata sepakat.22

${ }^{22}$ Raymond Hinnenbusch. UN Mediation in the Syrian Crisis: From Kofi Annan to Lakhdar Brahimi. London: Journal Intertantional Peace Institut. Sebagaimana dikutip oleh Didik Sugianto dan Arinto 
Pada Pasal 36 Statuta ayat (1) International Court of Justice (Mahkamah Internasional) dapat melakukan penyelesaian konflik Suriah, pasal tersebut menegaskan:

"The jurisdiction of the Court comprises all cases which the parties refer to it and all matters specially provided for in the Charter of the United Nations or in treaties and conventions in force".

Yurisdiksi Mahkamah terdiri dari semua kasus yang dirujuk oleh para pihak dan semua hal yang secara khusus diatur dalam Piagam Perserikatan Bangsa-Bangsa atau dalam perjanjian dan konvensi yang berlaku. Namun, berdasarkan pasal 34 statua ICJ, hanya negara yang dapat berperkara di mahkamah internasional. Tentu saja hal ini menarik karena Suriah merupakan negara anggota PBB dan Statuta. Akan tetapi perbuatan Suriah tidak ada merugikan negara lain, hal inilah yang membuat Suriah tidak dapat dituntut pada mahkahmah internasional.

Terdapat cara lain yang dapat digunakan untuk menyelesaikan masalah pemakaian senjata kimia ini, yaitu melaui SekJend PBB berdasarkan Pasal 99 Piagam PBB:

"The Secretary General may bring to the attention of the Secretary Council any matter, which in this opinion, may

Nugroho. Lihat Didik Sugianto dan Arinto Nugroho, Pertanggungjawaban Penggunaan Senjata Kimia Oleh Suriah Pada Tahun 2014-2015 Ditinjau Dari Hukum Humaniter Internasional, Jurnal Ilmiah Fakultas Ilmu Sosial dan Hukum, Universitas Negeri Surabaya, 2015. hal. 2-3.

Uti Possidetis: Journal of International Law, Vol. 3, No. 1 (2022) 
threaten the maintenance of international peace and Security".

Sekjen dapat memohon perhatian Dewan Sekretaris setiap hal, yang menurut pendapatnya dapat mengancam perdamaian dan Keamanan internasional. hal ini merupakan hak prerogatif dari Sekjen PBB. Hak Veto membuat tidak dimungkinkannya dewan keamanan untuk menyelesaikan kasus pemakaian senjata kimia di Suriah. Sekjen yang meminta Dewan Keamanan bahwa situasi di Suriah terutama dalam penggunaan senjata kimia dianggap telah membahayakan keamanan internasional, maka langkah selanjutnya yaitu Sekretaris Jenderal berperan berdasarkan Pasal 98 dan Pasal 99 Piagam PBB. ${ }^{23}$

Penyelesaian melalui Sekjen memiliki memiliki fungsi tambahan meskipun di lain sisi memiliki sifat politik yang sangat besar sesuai dengan fungsinya. Sekjen PBB secara tertulis mempunyai tanggung jawab politik dalam hal penyelesaian kasus penggunaan senjata kimia, tanggung jawab tersebut berupa memediatori supaya terjadi konsensus dalam penyelesaian kasus penggunaan senjata kimia. Dewan keamanan dapat melakukan rekomendasi untuk penunjukan

${ }^{23}$ Lihat Didik Sugianto dan Arinto Nugroho, Pertanggungjawaban Penggunaan Senjata Kimia Oleh Suriah Pada Tahun 20142015 Ditinjau Dari Hukum Humaniter Internasional, Jurnal Ilmiah Fakultas Ilmu Sosial dan Hukum, Universitas Negeri Surabaya. 2015. hal. 10 .

Uti Possidetis: Journal of International Law, Vol. 3, No. 1 (2022) 
wakil khusus untuk penyelesaian kasus ini, namun sebelumnya sudah ada Kofi Annan dan Lakhdar Brahimi untuk menyelesaikan konflik bersenjata non internasional di Suriah, namun hal itu gagal dikarenakan tidak tercapainnya suatu kesepakatan antara para pihak yang bertikai. ${ }^{24}$

Majelis Umum mempunyai fungsi melakukan penyelesaian sengketa secara damai. Akan tetapi dalam pelaksanaannya, majelis umum memiliki keterbatasan yang terdapat pada pasal 2 ayat (7) Piagam PBB. Pasal tersebut menjelaskan tak ada otorisasi kepada PBB untuk mencampuri masalah yang memang merupakan yurisdiksi nasional suatu negara. Tetapi hal ini tidak akan mengurangi kemungkinan dalam hal penerapan tindakan-tindakan pemaksaan yang dilakukan dalam rangka Bab VII Piagam PBB. ${ }^{25}$

Pada pasal 12 ayat (1) Piagam PBB menyatakan bahwa pada saat DK PBB melakukan tugasnya terkait situasi dan perselisihan sesuai dengan apa yang telah ditetapkan dalam Piagam PBB, Majelis Umum tidak dapat memberikan rekomendasi yang berkenaan dengan situasi dan perselisihan tersebut, kecuali Dewan Keamanan menghendakinya. Artinya, jika Dewan Keamanan dan Majelis Umum membicarakan hal yang sama, maka Majelis Umum sesuai dengan kewenanganya harus menghentikan sidangnya, kecuali Dewan Keamanan menghendakinya.

24 Ibid.

25 Ibid., hal. 11.

Uti Possidetis: Journal of International Law, Vol. 3, No. 1 (2022) 
Selanjutnya dari huruf A resolusi Majelis Umum PBB nomor 377 tahun 1950 Uniting for Peace Resolution menyatakan:

"Resolves that if the Security Council, because of lack of unamity of the permanent members, fails to exercise its primary responsibility for the maintenance of international peace and security in any case where there appears to be threat to the peace, or act of agression, the general assembly shall consider the matter immediately with a view to making appropriate recommendations to Member for collective measures, including in the case of a breach of the peace, or act of agression the armed forces when necessary to maintain or restore international peace and security. If not in session at the time, the General Assembly may meet in emmergency within twenty four hours of the request therefor. Such emmergency special session shall be called if requested by the Security Council on the vote of seven members, or by majority of the Members of the U.N."

Majelis Umum memiliki salah satu fungsi berupa dapat membicarakan situasi atau konflik yang tengah mengancam perdamaiandan keamanan internasional dalam waktu 24 jam ketika dewan keamanan gagal dalam mengambil keputusan. Atas dasar resolusi majelis umum, Dewan Keamanan dapat membicarakan masalah prosedural berupa memohon untuk segera melakukan sidang darurat khusus. Jika kita kembali pada kasus penggunaan senjata kimia oleh Suriah, maka dapat dilihat bahwa majelis umum danat diperlukan dalam 
melakukan penyelesaian permasalahan penggunaan senjata kimia oleh Suriah.

Majelis umum dapat mengeluarkan resolusi dari sidang darurat terkait dengan huru-hara yang terjadi di Suriah, selain itu majelis umum juga dapat mengeluarkan rekomendasi tentang pemeliharaan perdamaian dan kemanan internasional. Pengambilan keputusan dapat dilakukan melalui pemungutan suara, namun juga bisa dilakukan melalui konsensus. Kekuatan hukum dari resolusi majelis umum ini akan mengikat jika menyangkut perdamaian dan kemananan internasional, dan resolusi tersebut dapat bersifat rekomendasi untuk negara anggota ataupun dewan keamanan.

Jika kita lihat melalui majelis umum, pelaksaan peneyelesaian penggunaan senjata kimia di Suriah dapat dilakukan dengan melakukan pelucutan senjata kimia supaya tidak terulang lagi. Tindakan seperti ini dinilai dapat mengurangi bahkan menghilangkan senjata seperti itu supaya tidak dipakai sebagai metode perang. Pelepasan senjata kimia dinilai dibutukan untuk menghilangkan senjata kimia yang sudah beberapa kali digunakannya oleh Suriah.

Dasar hukum pelucutan senjata ini dapat dilihat pada Final Document. Dokumen tersebut merupakan bagian dari penutup dari dokumen yang dihasilkan pada sidang khusus Majelis Umum tahun 1978 yang membahas tentang pelucutan senjata. Terdapat hal penting yang berhubungan dengan pelucutan senjata ini, yaitu: 
"While the final objective of the efforts of all States should continue to be general and complete disarmament under effective international control, the immediate goal is that of the elimination of the danger of a nuclear war and the implementation of measures to halt and reverse the arms race and clear the path towards lasting peace."

Makna penting dari dokumen tersebut yaitu tentang tujuan akhir dari pelucutan senjata adalah pelucutan senjata umum dan menyeluruh dibawah pengawasan internasional. Mengenai pelucutan senjata yang umum dan menyeluruh pada poin 111 , disebutkan bahwa:

"General and complete disarmament under strict and effective international control shall permit States to have at their disposal only those non-nuclear forces, armaments, facilities and establishments as are agreed to be necessary to maintain internal order and protect the personal security of citizens and in order that States shall support and provide agreed manpower for a United Nations peace force."

Pelucutan senjata yang umum dan menyeluruh berarti senjata yang terdapat dinegara tersebut tidak harus di hancurkan. Negara masih diizinkan memiliki senjata yang bersifat non-nuklir untuk keperluan negaranya sendiri seperti menjaga ketertiban serta melindungi rakyatnya, dan memberikan bantuan kepada PBB dalam menjaga perdamaian.

Mengenai pembentukan pasukan penjaga perdamaian dan penggunaan pasukan bersenjata dilakukan ketika kondisi semakin memburuk. Pasukan ini dibentuk untuk 
menghentikan tindakan pelanggaran hukum humaniter di Suriah. Landasan hukum dalam pembentukan pasukan ini adalah pada pasal 42 piagam PBB. Pasukan ini dibentuk oleh dewan keamanan, namun jika terdapat ganjalan hak veto, maka majelis umum dapat mengambil peran dari dewan keamanan. Majelis umum juga dapat membentuk pasukan yang sama dengan dewan keamanan dengan didasarkan pada Uniting for Peace Resolution dalam emergency session.

Menurut hukum, pembetukan pasukan penjaga perdamaian merupakan tugas utama dari dewan keamanan. Karena adanya ganjalan hak veto, maka majelis umum memiliki peran untuk mengambil alih tugas tersebut dengan berdasarkan Resolusi Majelis Umum nomor 377 (V) tahun 1950.

\section{Penutup}

Di dalam hal penerapan The Chemical Weapons Convention 1993 "CWC" pada larangan penggunaan senjata kimia di negara Suriah yang merupakan anggota dari Persatuan Bangsa-Bangsa dan The Chemical Weapons Convention 1993 terbukti telah menggunakan senjata kimia didalam konflik yang terjadi di negara tersebut. Seperti yang telah diatur didalam Konvensi Den Haag 1907 mengenai tata cara dan alat berperang, penggunaan senjata kimia dilarang untuk dipergunakan. Hingga saat ini, sanksi yang didapat oleh Suriah hanyalah pemusnahan senjata kimia saja, padahal 
dalam kasus penggunaan senjata kimia oleh Suriah sebenarnya dapat diajukan ke Mahkamah Pidana Internasional dan mungkin akan dijatuhkan sanksi yang setimpal dengan perbuatan Suriah.

\section{Referensi}

Ambarwati, dkk. Hukum Humaniter Internasional dalam Studi Hubungan Internasional. Cetakan Pertama, Rajawali Pers, Jakarta, 2009

Convention on the Prohibition of the Development, Production, Stockpiling and Use of Chemical Weapons and on their Destruction (The Chemical Convention 1993)

Convention (IV) respecting the Laws and Customs of War on Land and its annex: Regulations concerning the Laws and Customs of War on Land (The Hague Convention 1907)

Couloumbus, T.A. and James H. Wolfe. Introduction to International Relations: Power and Justice. New Jersey: Prentice hall Inc., 1990

Gama Prabowo. Sejarah Terjadinya Konflik di Suriah.Dimuat dalamhttps://www.kompas.com/skola/read/2020/12 /02/143230769/sejarah-terjadinya-konflik-di =suriah?page=all. Diakses pada tanggal akses 17 September 2021.

Kusumaatmadja, Mochtar dan Etty R. Agoes. Pengantar Hukum Internasional. Edisi Ke-2, Bandung: PT. Alumni, 2003 
Mariwala, Arnav. The Syrian Civil War Regime of Bashar Al Assad. Standford Model United Nation Conference. 2014

Nasution, Hanna Safira. Penyalahgunaan Wewenang Oleh Pejabat Diplomatik Dalam Melaksanakan Tugas Diplomatiknya Ditinjau Dari Aspek Hukum Internasional. Jurnal Ilmu Hukum, 2017.

Niken Purnamasari. Mengenal Gas Sarin yang Membunuh Perlahan Anak-anak Suriah. https://news.detik.com/berita/d-3467871/mengenalganasnya-gas-sarin-yang-membunuh-perlahan-anakanak-suriah. Diakses pada tanggal 29 Desember 2020 Pukul 15:44 WIB

Opcw. OPCW Releases First Report by Investigation and Identification Team. https://www.opcw.org/mediacentre/news/2020/04/opcw-releases-first-report investigation-and-identification-team. Diakses pada tanggal 29 Desember 2020 Pukul 15:44 WIB

Protocol for the Prohibition of the Use in War of Asphyxiating, Poisonous or other Gases, and of Bacteriological Methods of Warfare (Geneva Convention 1925)

Raymond Hinnenbusch. UN Mediation in the Syrian Crisis: From Kofi Annan to Lakhdar Brahimi. London: Journal Intertantional Peace Institut. Jurnal Ilmiah Fakultas Ilmu Sosial dan Hukum, Universitas Negeri Surabaya, 2015

Republika Post. Konflik Suriah Lebih Lama dari Dua Perang Dunia.https://www.republika.id/posts/15027/konflik -suriah-lebih-lama-dari-dua-perang-dunia. Diakses pada tanggal 17 September 2021.

Rome Statue of The International Court 1998 
Sholihan. "Memahami Konflik," dalam Mukhsin Jamil (Ed), Mengelola Konflik Membangun Damai. Semarang: Wali Songo Media Center. 2007.

Steffi. Tinjauan Hukum Internasional Terhadap Kasus Penggunaan Senjata Kimia Oleh Suriah. Jurnal Ilmiah 2014

Sugianto, Didik dan Arinto Nugroho. Pertanggungjawaban Penggunaan Senjata Kimia Oleh Suriah Pada Tahun 2014-2015 Ditinjau Dari Hukum Humaniter Internasional. Jurnal Ilmiah Fakultas Ilmu Sosial dan Hukum, Universitas Negeri Surabaya, 2015.

St. Petersburg Convention Declaration Relating to Explosive Projectiles 1868

War and International Humanitarian Law. dimuat dalam http://www.icrc.org/eng/war-and-law/overview-warand-law.html. diakses pada 30 September 2020, Pukul 11:06 WIB 